\title{
Tourism Statistics and the Business Register in Italy: A Comparative Analysis and future Outlooks for Integration
}

\author{
Francesca Petrei and Maria Teresa Santoro*
}

\begin{abstract}
After the proposal of a possible insertion of tourism statistics (supply side) (TS) into Framework Regulation Integrating Business Statistics (FRIBS) on which an interesting debate is in progress between Eurostat and NSIs, Istat (Italian Institute of Statistics) has started a costs/benefits analysis of this integration. ASIA (Statistical Register of Active Enterprises), built up by Istat, represents in Italy the official source about the structure and the economic performance of the enterprises. ASIA, whose statistical units are enterprises of industry and services, has been developed through the statistical integration of different administrative sources, other minor archives available (covering particular sectors) and structural business statistics currently produced by Istat. The supply side TS are produced by Istat through surveys via Intermediate Bodies (Local Authorities): each Intermediate Body has its own local register of accommodation establishments based on Local Kind-of-activity unit (LKAU). In this paper, the results of a comparative analysis between the statistical units as recorded in ASIA and as surveyed by TS are presented; from first outcomes, considerable issues about data quality appear both at level of coverage for the three Nace groups of the TS (also underlined in the Methodological Manual on Tourism Statistics where for Italy a difference of $70 \%$ is reported) and for loss information relating to the location of the activities (switching from LKAU to Enterprises) as well as for timeliness (ASIA has two years of delay). Then, the administrative local tourism registers (LTR) are analysed to understand: how many they are, their dissemination in the Italian territories, their primary purpose and source, the variables contained, the frequency of updates. This preliminary analysis is needed to identify the operative activities that Istat, together with the Intermediate Bodies, should start to use administrative archives for statistical purposes and to develop a unique tourism satellite archive (TSA), facing many difficulties related to the reception of several LTR as well as methodological issues for record linkage. On the other hand, a TSA would lead numerous advantages: a unique and official list of internal accommodation establishments; a step towards integration of TS into FRIBS; a starting point to begin to use also administrative data produced by the Italian Police (mandatory communications on guests in the interests of public safety), having a comparison term to assess their coverage.
\end{abstract}

Keywords: business register, tourism statistics, integration between administrative and statistics source.

\section{Introduction and Reference Framework ${ }^{1}$}

The Framework Regulation Integrating Business Statistics (FRIBS) project aims at establishing a cross-cutting framework regulation to integrate business statistics. It is targeted to bring integration,

\footnotetext{
*Istat, Short-term Economic Statistics Directorate; email: petrei@istat.t - masantor@istat.it

1 The views expressed in this paper are solely of the authors and do not necessarily reflect those of Istat. The contribution is the fruit of joint work of the two authors. However, the paragraphs may be attributed as follows: M.T. Santoro paragraphs 1 and 2, F. Petrei paragraphs 3 and 4 .
} 
streamlining, flexibility and a reduction of the response burden in business statistics in the EU.

The operational objective of this project is to establish, by the end of 2016, a common legal framework for the systematic collection, compilation, transmission and dissemination of European statistics related with the structure, economic activity, competitiveness, global transactions and performance of the business sector in EU. However, it will not be a mere consolidation of the existing legal acts in the individual business statistics domains, but a challenging project that will rely on a critical revision of the existing data requirements, methodological arrangements, implementing provisions and on an in depth analysis of the users requirements.

FRIBS will cover statistical domains measuring business activities such as:

- infra-annual statistics: short term business statistics, international trade in goods statistics and business demography;

- annual and multiannual statistics: structural business statistics, production statistics, international trade in services statistics, foreign affiliate statistics, innovation, $R \& D$, foreign direct investment statistics, information society, and science, technology and innovation statistics;

- other business related statistics: tourism statistics (supply side) and other business related statistics may be added to the project.

Therefore, a new framework for all economic statistics seems to arise that could also involve part of the tourism statistics (TS).

Currently, TS, starting from the data regarding the year 2012, are produced under the Regulation (EU) $\mathrm{n}$. 692/2011. The Regulation considers two parts within TS (as specified in the two annexes of the Regulation):

(1) the supply side (data on capacity and occupancy of tourist accommodation establishments), closely linked to a business statistics approach;

(2) the demand side (data on tourism demand collected via interviews of households), closely linked to a social statistics approach.

Only the first part, the supply side or accommodation statistics (the so-called "tourism package"), is relevant for integration into FRIBS. Considering the very recent adoption of the Regulation 692/2011 and the significant changes it contains, at first stage, there will be not an explicit review of the existing data requirements, methodological arrangements and implementing provisions. Nevertheless, certain updates and changes will be possibly necessary in order to guarantee a smooth integration rather than a mere consolidation.

Obviously the proposed integration of part of TS into FRIBS has started an interesting debate between the Member States (MS) that, depending on their needs and experiences, are in favor or against.

From the conceptual point of view, the main argument in favor of this integration, shared by most of the MS, is that, being the tourism sector a fully-fledged economic activity, it will improve consistency and comparability with other business statistics, which would significantly increase the relevance of TS. On the other hand, the main argument against is the loss of an integrated approach or common framework between supply and demand side statistics on tourism, principal objective of the Regulation 692/2011.

From the methodological point of view, the two major issues identified for integrating TS into FRIBS relate to the currently used tourism registers and the statistical units. They represent potential blocking factors for a fast insertion and in particular:

(1) tourism registers: very specific tourism registers are at the base of data collection in the framework of the Regulation 692/2011 (whereas business registers play a central role in FRIBS). These tourism registers are in many cases maintained and updated by bodies other than the statistical office and as such they are not or not 
Analysis and future Outlooks for Integration

yet integrated as satellite registers to the general business register;

(2) statistical units: this aspect is interrelated with the issue of the registers. While FRIBS has enterprise as its main statistical unit, the current legal framework for TS lays down the local kind-of-activity unit (LKAU) for Nace rev. 2 55.1, 55.2 and 55.3 as the statistical unit for accommodation statistics. The choice for this statistical unit was twofold:

- the local unit is needed to sufficiently cover the territorial dimension of tourism (and not allocate all nights and arrivals to the region where a hotel chain's headquarters is located);

- the kind-of-activity unit is needed to sufficiently cover those cases where accommodation is not the main activity of an enterprise.

From the technical and operative point of view, each MS carries out surveys with different methodologies and procedures, introducing into the debate more critical elements in achieving effective integration of TS into FRIBS.

In Italy, Istat - the National Institute of Statistics - has started a costs/benefits analysis of this integration to understand what are the technical and operative issues to deal and the feasibility of this project.

\section{The Italian case: A Comparative Analysis between Business Register and Tourism Statistics}

In this paragraph, after a short description of the main features of the two sources, the results of a comparative analysis between the statistical units as recorded in Statistical Registers of Active Enterprises (ASIA) and as surveyed by TS are presented.

\section{The Statistical Business Register "ASIA"}

ASIA is the Italian Statistical Register of Active Enterprises and it is used by Istat in its economic surveys. It was created in 1996 in application of Council Regulation (EEC) n. 2186/93. ASIA-Enterprises (ASIA-E.) comprises identification data (name, location), structural data (employees, core and secondary economic activity, legal status, turnover) and demographic data (business start date, business termination date, state of activity, possible insolvency proceedings) of all enterprises ${ }^{2}$, active ${ }^{3}$ in all sectors of the economy (except for Sections A, O, T and U, and private non-profit bodies) as per Ateco ${ }^{4}$ classifications (version 2007).

It was created and updated annually integrating various legal, administrative and tax collection archives. ASIA is further updated using information deducible from all statistical surveys on enterprises.

Its location variables relate to the enterprise's administrative offices meaning the place where the enterprise carries out its business and where the main administrative/management offices are located.

At the end of the first quarter of each year the final version, containing the variables updated at $t-2$, of the register is available.

The need to understand and represent at local level the evolution of the economic structure of the country and to comply with EU Regulations, led in 2004 to the implementation in ASIA of an additional level: ASIA-Local units (ASIA-L.U.). Each year Istat issues data on enterprise local units ${ }^{5}$ and their employees derived from ASIA. The field of observation of ASIA-L.U. is the same as ASIA-E. and covers all industrial,

\footnotetext{
2 An enterprise: a legally recognised organisational unit carrying out one or more activities at one or more locations; enterprises are classified into sectors (by Nace) according to their main activity.

3 For ASIA an enterprise is "active" if it has done real productive activity for at least six months in the year.

4 The national version of the Nace Rev.2 classification.

5 A local unit: an enterprise or part of an enterprise (factory, warehouse, office) situated in one geographically identified place; local units are classified into sectors (by Nace) according to their main activity.
} 
commercial and service-sector activities. ASIA-L.U. was developed through a direct survey of local units belonging to larger-size enterprises and of administrative sources that provide information on individual local units, as well as through traditional enterprise surveys. The information includes the municipal location, type of economic activity and number of employees.

At the end of each year the final version, containing the variables updated at $t-2$, of the register is available.

\section{The Surveys on Tourism Statistics (Supply Side)}

The unit "Tourism statistics" SER/B of Istat carries out two surveys on tourism, supply-side.

The census survey "Capacity of tourist accommodation establishments" collects each year, at municipality level, the number of establishments, bed places, bedrooms and bathrooms for hotels and similar accommodation (LKAU ${ }^{6}$ referring to Nace rev.2 group 55.1), classified with stars from 5 to 1 or hotel-tourism residences, and the number of establishments and bed places for other collective accommodations (LKAU referring to Nace rev.2 groups 55.2 e 55.3), grouped in tourist camp-sites, holiday villages, farm houses, youth hostels, holiday dwellings, B\&B, etc..

The census survey "Occupancy of tourist accommodation establishments" collects each month, at municipality level, data on arrivals and nights spent by residents and non-residents at tourist accommodation establishments, divided by category of hotels and similar accommodation, and by type of the other collective accommodation establishments. Data are broken down by country of residence in the case of non-residents, and by region of residence for Italian residents. Moreover, it also provides information to calculate the occupancy rates of bed places and bedrooms for hotels and similar accommodation.

Istat carries out the surveys through local authorities that play the role of Intermediate Bodies. They may be statistical offices of the Provinces or Regions or other Local Authorities responsible for tourism, depending on the organizational structure of each region, that moreover can have different territorial level of management of the surveys: regional, provincial, sub-provincial.

This organization is due to the fact that, in Italy, the legislative competence in the field of tourism is attributed to the Regions ${ }^{7}$ and, consequently, all the related administrative functions. The tourism data collection, then, can be defined as a "variable-geometry", involving the participation of various territorial levels, depending on the Regions that, in their autonomy, are organized each one in a different way. In most cases, the phases of data collection, recording, processing, checking and transmission to Istat are performed by at least two entities.

These different organizational modalities have a significant impact on the size of the data production chain, namely on the number of intermediate steps between the micro-data collection phase and the final phase of data transmission to Istat.

Furthermore, the result is also a situation of lack of uniformity regarding the local tourism registers (LTR) that, as shown later (paragraph 3), are very numerous and different each other.

\footnotetext{
${ }^{6}$ A local kind-of-activity unit is a combination of local unit (see footnote n. 4) and kind-of-activity unit (abbreviated as KAU, that is an enterprise or part of an enterprise which in its entirety can be classified within one activity sector by Nace): an enterprise or part of an enterprise situated in one geographically identified place which in its entirety can be classified within one activity sector (by Nace).

${ }^{7}$ Reform of Title V, Part 2, of the Constitution and Constitutional law of 18 October 2001 n. 3, Art. 117, fourth paragraph.
} 
Analysis and future Outlooks for Integration

\section{The Results of the Comparative Analysis}

TS are based on the LTR, whose statistical units of reference are the LKAU, as required by the Regulation (EU) n. 692/2011. These registers are currently managed by the local bodies.

On the other hand, ASIA represents the universe of reference for the economic surveys carried out by Istat. The statistical units of reference of ASIA are, respectively, the enterprise for ASIA-E. and the local unit for ASIA-L.U.

A first problem derives from the different concept of statistical unit of reference of the two types of registers (LTR vs ASIA); in fact, one enterprise can have a number of local units and/or kind-of-activity units. One local unit can comprise several LKAU. It is possible that the main activity of a local unit is not the same as the one of the enterprise to which it belongs.

Before dealing with the results of the analysis, we have to point out that, unfortunately at the moment Istat can't validate the information about the secondary activity of the units in ASIA registers, due to a lack of human resources. So, the comparison is made just considering the units in ASIA with the primary activity into Nace rev.2 groups 55.1, 55.2 and 55.3 (tourism accommodation sector).

The comparative analysis between the units classified into the three groups for the two sources, ASIA registers and the survey Capacity of tourist accommodation establishments (CAP), for the year $2011^{8}$ shows a significant difference in terms of number of units: 153,723 units for CAP, 45,747 for ASIA-E. and 50,487 for ASIA-L.U. that means $-70.2 \%$ units in ASIA-E. and $-67.2 \%$ units in ASIA-L.U. compared to CAP, with a greater difference for the group 55.2.

Table 1

Number of statistical units in the tourist accommodation sector: comparison of Capacity survey and ASIAYear 2011

\begin{tabular}{lllll}
\hline Source & Nace rev.2 & & & TOTAL \\
\cline { 2 - 4 } & 55.1 & 55.3 & 55.2 & 153,723 \\
\hline Absolute values & & & & 45,747 \\
\hline CAP. & 33,918 & 2,348 & 117,457 & 50,487 \\
ASIA-E. & 24,734 & 1,677 & 19,336 & 20,479 \\
ASIA-L.U. & 28,107 & 1,901 & & -70.2 \\
\hline \% differences ASIA vs Capacity data & & & -83.5 & -67.2 \\
\hline ASIA-E. & -27.1 & -28.6 & -82.6 & -19.0 \\
ASIA-L.U. & -17.1 & & & \\
\hline
\end{tabular}

Source: elaborations on Istat data

From the previous table, it is clear that the results for the three groups is quite different; in fact, for the group 55.1 Hotels and similar accommodation and 55.3 Camping grounds, recreational vehicle parks and trailer parks, the difference is, respectively, $-27.1 \%$ and $-28.6 \%$ for ASIA-E. and $-17.1 \%$ and $-19.0 \%$ for ASIA L.U.; for the group 55.2 Holiday and other short-stay accommodation this difference increases to, respectively, $-83.5 \%$ and $-82.6 \%$.

So, the most problematic situation concerns the accommodation establishments classified into 55.2. Before examining the results of the comparison concerning its components, a clarification is needed: while ASIA

\footnotetext{
${ }^{8}$ Last available year for ASIA registers.
} 
registers classify the units until the 5-digit level of Ateco, the CAP has a greater level of detail (more than the 6-digit level of Ateco) (see table n. 2).

Table 2

Correspondence table: tourist accommodation establishments by type, according to the Capacity survey and by Ateco 2007 - classification at 5-digit level (ASIA) and at 6-digit level

\begin{tabular}{lll}
\hline \multicolumn{2}{l}{ Nace rev. 2 55.2 Holiday and other short-stay accommodation: } \\
\hline By type, according to the Capacity survey & \multicolumn{2}{l}{ by Ateco 2007 } \\
\cline { 2 - 3 } 6-digit level & 5-digit level (ASIA) \\
\hline Holiday villages & 55.20 .10 & 55.20 .1 \\
Youth hostels & 55.20 .20 & 55.20 .2 \\
Mountain refuges & 55.20 .30 & 55.20 .3 \\
Holiday homes & 55.20 .40 & 55.20 .4 \\
Holiday dwellings (rented) & 55.20 .51 & 55.20 .5 \\
B\&B & 55.20 .51 & 55.20 .5 \\
Other accommodation n.e.c. & 55.20 .51 & 55.20 .5 \\
Farmhouses & 55.20 .52 & 55.20 .5
\end{tabular}

Table 3

Number of statistical units into the group 55.2: comparison of Capacity survey and ASIA - Year 2011

\begin{tabular}{|c|c|c|c|c|c|c|c|c|c|c|}
\hline \multirow{4}{*}{ Source } & \multicolumn{10}{|c|}{ Nace rev. 2} \\
\hline & 55.20 .1 & 55.20 .2 & 55.20 .3 & 55.20 .4 & \multicolumn{4}{|c|}{55.20 .5} & $\begin{array}{l}\text { TOTAL } \\
55.20 .5 \\
\end{array}$ & $\begin{array}{l}\text { TOTAL } \\
55.2 \\
\end{array}$ \\
\hline & & & & & 55.20 .51 & 55.20 .51 & \multicolumn{2}{|c|}{55.20 .5155 .20 .52} & & \\
\hline & $\begin{array}{l}\text { Holiday } \\
\text { villages }\end{array}$ & $\begin{array}{l}\text { Youth } \\
\text { hostels }\end{array}$ & $\begin{array}{l}\text { Mountain } \\
\text { refuges }\end{array}$ & $\begin{array}{l}\text { Holiday } \\
\text { homes }\end{array}$ & $\begin{array}{c}\text { Holiday } \\
\text { dwellings } \\
\text { (rented) }\end{array}$ & $\begin{array}{c}\text { Other } \\
\text { accommodation } \\
\text { n.e.c. } \\
\end{array}$ & $\mathrm{B} \& \mathrm{~B}$ & Farmhouses & & \\
\hline & \multicolumn{10}{|c|}{ Absolute values } \\
\hline CAP. & 311 & 463 & 1,041 & 2,258 & 71,975 & 415 & 23,857 & 17,137 & 113,384 & 117,457 \\
\hline ASIA-E. & 842 & 172 & 861 & 223 & & & & & 17,238 & 19,336 \\
\hline \multirow[t]{2}{*}{ ASIA-L.U. } & 1,057 & 205 & 949 & 281 & + & 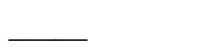 & & & 17,987 & 20,479 \\
\hline & \multicolumn{10}{|c|}{$\%$ differences ASIA vs Capacity data } \\
\hline ASIA-E. & 170.7 & -62.9 & -17.3 & -90.1 & & & & & -84.8 & -83.5 \\
\hline ASIA-L.U. & 239.9 & -55.7 & -8.8 & -87.6 & & & & & -84.1 & -82.6 \\
\hline
\end{tabular}

Source: elaborations on Istat data

Analyzing the results of the comparison of each component of the group 55.2 (tab. 3), it arises that:

- the category 55.20.3 Mountain refuges seems to be the only one to achieve a good level of coverage in the ASIA registers in comparison to CAP, recording a slight difference -17.3 and -8.8 in terms of units in ASIA registers vs CAP;

- the category 55.20.2 Youth hostels has a higher difference (-62.9\% and 55.7\% between ASIA registers and CAP);

- the category 55.20.4 Holiday homes has very significant differences $-90.1 \%$ and $-87.6 \%$ between ASIA registers and CAP;

- the category 55.20.1 Holiday villages presents, on the contrary, figures much higher in ASIA registers than CAP, even three times higher. This can be attributed to a classification issue: in fact, for CAP into 55.20.1 
Analysis and future Outlooks for Integration

are classified only the holiday villages strictu sensu, while the campgrounds and the so-called campgrounds-holiday villages in mixed form fall into 55.3. Probably, in the ASIA registers the so-called mixed forms are recorded into 55.20.1; in fact, adding the units of the group 55.3 and the units of the category 55.20.1, basically there is no difference between ASIA registers and CAP (see table n. 4).

Table 4

Number of statistical units in 55.3 and 55.20.1: comparison of Capacity survey and ASIA - Year 2011

\begin{tabular}{llll}
\hline Source & 55.3 & 55.20 .1 & TOTAL \\
\hline CAP. & 2,348 & 311 & 2,659 \\
ASIA-E. & 1,677 & 842 & 2,519 \\
ASIA-L.U. & 1,901 & 1,057 & 2,958 \\
\hline
\end{tabular}

Source: elaborations on Istat data

- the category 55.20.5 is the most complex to analyze because it includes four types of accommodation establishments that are broken down in CAP. The difference in ASIA registers is quite high, around $-85 \%$. In addition to the problem of the different statistical unit of reference, there are other issues, in particular connected to two specific types of accommodation: B\&B and farmhouses. In both cases, they are not strictly included into the scope of observation of ASIA: the first ones because of their nature, many B\&B are not qualified as enterprises by the laws in force in Italy; the second ones because they, being secondary activities connected to the main activity "Agriculture" (Section A - Agriculture, Forestry and Fishing in Nace rev. 2), are not covered by the ASIA registers. It means that approximately 24,000 B\&B and 17,000 farmhouses are not present in ASIA registers.

Substantial differences arise, obviously, when the comparative analysis is carried out at regional level, because there is a considerable variability between the regions. The discrepancy of the number of units in some regions is very far from the Italian average (which, as already said, is equal to about $-70 \%$ ). Very high differences occur, for example, in Veneto (respectively $-93.7 \%$ and $-92.8 \%$ CAP vs ASIA-E. and ASIA-L.U.) and Friuli-Venezia Giulia (-85.5\% and $-84.5 \%)$. On the other hand, there are regions that have a number units present in the registers a little less distant from the results of CAP; for example, the Autonomous Province of Trento (-40.3\% and $-33.7 \%$ ) and Lombardia (-46.4\% and $-39.0 \%$ ) (see table n. 5).

Breakdowning the results by the three groups, the most significant differences are, obviously, for the 55.2: only the Autonomous Provinces of Bolzano and Trento register differences of about $-50 \%$, while all the other regions have very low values in the registers, with the limit cases of Veneto, that presents the highest difference (-97.9\% for ASIA-E. and -97.8\% for ASIA-L.U.) and Friuli-Venezia Giulia (respectively $-94.5 \%$ and $-95 \%$ ).

Regarding the other two groups 55.1 e 55.3, the differences between the units in ASIA registers and CAP are lower and more homogeneous across the regions.

However, it has to be pointed out that some regions have a number of units in Asia-L.U. higher compared to CAP, although not too much; in particular, for the group 55.1, Campania has a positive difference (2.8\%), while, for the group 55.3, positive differences are in Lazio (8.7\%), Lombardia (8.3\%), Basilicata (8.3\%), Sardegna (3.6\%) and Veneto (0.6\%) (see table n. 6).

However, through ASIA-L.U. has taken a first step forward from the point of view of the territorial detail (compared to ASIA-E. register), but to understand the size of the Capacity of tourism accommodation establishments in its localization and its entirety, the detail of the LKAU is undoubtedly better and essential. 
Analysis and future Outlooks for Integration

Table 5

Number of statistical units in the tourist accommodation sector (Nace rev. 2 division 55) by region and geographical macro-area: comparison of Capacity survey and ASIA - Year 2011

\begin{tabular}{|c|c|c|c|c|c|}
\hline \multirow{2}{*}{ region/geographical macro area } & \multicolumn{3}{|c|}{ Absolute values } & \multicolumn{2}{|c|}{$\%$ differences ASIA vs Capacity data } \\
\hline & CAP. & ASIA-E. & Asia-L.U. & ASIA-E. & Asia-L.U. \\
\hline PIEMONTE & 5,292 & 1,820 & 2,040 & -65.6 & -61.5 \\
\hline VALLE D'AOSTA & 1,031 & 551 & 592 & -46.6 & -42.6 \\
\hline LOMBARDIA & 6,618 & 3,545 & 4,038 & -46.4 & -39.0 \\
\hline LIGURIA & 4,144 & 1,869 & 2,056 & -54.9 & -50.4 \\
\hline NORTH WEST & 17,085 & 7,785 & 8,726 & -54.4 & -48.9 \\
\hline BOLZANO - BOZEN & 10,266 & 5,404 & 5,503 & -47.4 & -46.4 \\
\hline TRENTO & 2,843 & 1,698 & 1,884 & -40.3 & -33.7 \\
\hline VENETO & 55,892 & 3,525 & 4,027 & -93.7 & -92.8 \\
\hline FRIULI-VENEZIA GIULIA & 4,781 & 695 & 740 & -85.5 & -84.5 \\
\hline EMILIA-ROMAGNA & 8,413 & 4,370 & 4,816 & -48.1 & -42.8 \\
\hline NORTH - EAST & 82,195 & 15,692 & 16,970 & -80.9 & -79.4 \\
\hline TOSCANA & 12,051 & 5,548 & 6,125 & -54.0 & -49.2 \\
\hline UMBRIA & 3,849 & 1,195 & 1,297 & -69.0 & -66.3 \\
\hline MARCHE & 3,744 & 1,294 & 1,400 & -65.4 & -62.6 \\
\hline LAZIO & 8,506 & 3,135 & 3,467 & -63.1 & -59.2 \\
\hline CENTRE & 28,150 & 11,172 & 12,289 & -60.3 & -56.3 \\
\hline ABRUZZO & 2,373 & 1,172 & 1,276 & -50.6 & -46.2 \\
\hline MOLISE & 424 & 174 & 186 & -59.0 & -56.1 \\
\hline CAMPANIA & 6,665 & 2,864 & 3,195 & -57.0 & -52.1 \\
\hline PUGLIA & 4,689 & 1,826 & 2,056 & -61.1 & -56.2 \\
\hline BASILICATA & 667 & 309 & 335 & -53.7 & -49.8 \\
\hline CALABRIA & 2,597 & 1,137 & 1,263 & -56.2 & -51.4 \\
\hline SOUTH & 17,415 & 7,482 & 8,311 & -57.0 & -52.3 \\
\hline SICILIA & 4,849 & 2,341 & 2,609 & -51.7 & -46.2 \\
\hline SARDEGNA & 4,029 & 1,275 & 1,582 & -68.4 & -60.7 \\
\hline ISLANDS & 8,878 & 3,616 & 4,191 & -59.3 & -52.8 \\
\hline ITALY & 153,723 & 45,747 & 50,487 & -70.2 & -67.2 \\
\hline
\end{tabular}

Source: elaborations on Istat data

Table 6

Number of statistical units in the tourist accommodation sector (Nace rev. 2 groups 55.1 - 55.2 - 55.3) by region and geographical macro-area: comparison of Capacity survey and ASIA - Year 2011

\begin{tabular}{|c|c|c|c|c|c|c|c|c|}
\hline \multirow{2}{*}{$\begin{array}{l}\text { region/ } \\
\text { geographical macro area }\end{array}$} & \multicolumn{4}{|c|}{$\%$ differences ASIA-E. vs CAP. data } & \multicolumn{4}{|c|}{$\%$ differences ASIA-L.U. vs CAP. data } \\
\hline & 55.1 & 55.3 & 55.2 & TOTALE & 55.1 & 55.3 & 55.2 & TOTALE \\
\hline PIEMONTE & -34.4 & -25.6 & -80.9 & -65.6 & -23.9 & -19.0 & -79.6 & -61.5 \\
\hline VALLE D'AOSTA & -31.5 & -41.0 & -62.3 & -46.6 & -27.2 & -37.7 & -58.6 & -42.6 \\
\hline LOMBARDIA & -24.1 & -3.6 & -67.8 & -46.4 & -10.9 & 8.3 & -65.5 & -39.0 \\
\hline LIGURIA & -30.4 & -10.1 & -72.6 & -54.9 & -22.2 & -1.4 & -70.5 & -50.4 \\
\hline NORTH WEST & -28.6 & -15.9 & -73.4 & -54.4 & -17.9 & -7.3 & -71.5 & -48.9 \\
\hline BOLZANO - BOZEN & -43.2 & -20.0 & -50.5 & -47.4 & -41.4 & -15.6 & -50.2 & -46.4 \\
\hline TRENTO & -23.3 & -76.1 & -56.4 & -40.3 & -14.6 & -72.6 & -52.1 & -33.7 \\
\hline VENETO & -25.3 & -18.7 & -97.9 & -93.7 & -12.9 & 0.6 & -97.8 & -92.8 \\
\hline FRIULI-VENEZIA GIULIA & -38.2 & -55.2 & -94.5 & -85.5 & -29.5 & -51.7 & -95.0 & -84.5 \\
\hline
\end{tabular}


Analysis and future Outlooks for Integration

Table 6 continued

\begin{tabular}{|c|c|c|c|c|c|c|c|c|}
\hline \multirow{2}{*}{$\begin{array}{l}\text { region/ } \\
\text { geographical macro area }\end{array}$} & \multicolumn{4}{|c|}{$\%$ differences ASIA-E. vs CAP. data } & \multicolumn{4}{|c|}{$\%$ differences ASIA-L.U. vs CAP. data } \\
\hline & 55.1 & 55.3 & 55.2 & TOTALE & 55.1 & 55.3 & 55.2 & TOTALE \\
\hline EMILIA-ROMAGNA & -21.9 & -39.3 & -79.0 & -48.1 & -13.2 & -30.3 & -77.8 & -42.8 \\
\hline NORTH - EAST & -30.1 & -46.7 & -91.8 & -80.9 & -22.6 & -37.4 & -91.5 & -79.4 \\
\hline TOSCANA & -27.0 & -21.1 & -63.5 & -54.0 & -15.0 & -6.2 & -61.3 & -49.2 \\
\hline UMBRIA & -33.7 & -25.0 & -75.7 & -69.0 & -22.2 & -17.5 & -74.7 & -66.3 \\
\hline MARCHE & -24.5 & -58.9 & -79.6 & -65.4 & -15.1 & -54.0 & -79.0 & -62.6 \\
\hline LAZIO & -16.9 & -4.7 & -78.8 & -63.1 & -4.5 & 8.7 & -77.8 & -59.2 \\
\hline CENTRE & -24.1 & -28.7 & -72.0 & -60.3 & -12.4 & -17.6 & -70.5 & -56.3 \\
\hline ABRUZZO & -16.7 & -25.9 & -71.4 & -50.6 & -6.7 & -18.5 & -70.4 & -46.2 \\
\hline MOLISE & -33.0 & -7.1 & -70.4 & -59.0 & -28.3 & -7.1 & -68.1 & -56.1 \\
\hline CAMPANIA & -11.2 & -19.3 & -74.0 & -57.0 & 2.8 & -14.9 & -72.2 & -52.1 \\
\hline PUGLIA & -21.5 & -23.3 & -73.8 & -61.1 & -6.3 & -12.0 & -72.1 & -56.2 \\
\hline BASILICATA & -27.4 & -8.3 & -69.6 & -53.7 & -19.2 & 8.3 & -68.4 & -49.8 \\
\hline CALABRIA & -37.9 & -32.7 & -67.3 & -56.2 & -29.7 & -28.2 & -64.1 & -51.4 \\
\hline SOUTH & -20.4 & -24.1 & -72.5 & -57.0 & -8.4 & -17.0 & -70.7 & -52.3 \\
\hline SICILIA & -23.2 & -16.5 & -63.7 & -51.7 & -10.8 & -11.0 & -60.8 & -46.2 \\
\hline SARDEGNA & -31.4 & -21.7 & -81.0 & -68.4 & -14.8 & 3.6 & -76.6 & -60.7 \\
\hline ISLANDS & -26.6 & -19.0 & -71.8 & -59.3 & -12.4 & -4.0 & -68.2 & -52.8 \\
\hline ITALY & -27.1 & -28.6 & -83.5 & -70.2 & -17.1 & -19.0 & -82.6 & -67.2 \\
\hline
\end{tabular}

Source: elaborations on Istat data

From the analysis of the characteristics of the ASIA registers and the results of the comparative analysis between their units and the Capacity data, can be made some considerations, useful to understand if currently there are or not the requirements for an integration of TS into FRIBS: undoubtedly, there are several critical factors that seem to discourage the use of the ASIA registers for TS, at least in the short term, which can be summarized as follows:

- different statistical unit of reference;

- difficulty in determining the KAU: ASIA registers don't validate the secondary activity;

- timeliness of the ASIA registers that have a two-year delay in relation to the data of Capacity;

- low/partial coverage in the ASIA registers of the three groups (especially for some specific type of accommodation) vs the universe of reference for the Capacity survey;

- ASIA does not have all the information required in the Regulation 692/2011 (number of beds or number of rooms, etc.).

\section{The Administrative Tourism Registers}

In Italy, at the moment, there is not a general tourism register ${ }^{9}$ with the requirements to carry out surveys

\footnotetext{
${ }^{9}$ Recently (October 2013) the Government has announced the ENIT (Italian National Agency for Tourism) will develop the national digital register of the tourism accommodation establishments, within the framework of the Agenda Digitale project, i.e. the process of digitizing the country. At the time, however, the way and the timing of implementation of the project are unknown. For completeness, we have to enumerate also another administrative source, deriving from legal obligation, that establishes that the tourism accommodation managers are required to communicate to the competent territorial police stations, using computer or electronic means or by fax, the details of their guests within 24 hours after their arrival, according to specific rules (Decree of the Minister of Interior of 7/01/ 2013). The Ministry of Interior manages these data, but, because of their nature, purely administrative, there is not a check on the coverage so that, at present, they can't be used for statistical purposes. Istat has already made a prototype of a feasibility study on the use of these administrative data for statistical purposes and has started initial contacts with the Chief of the Police to pursue a joint activity with the Ministry of Interior.
} 
on tourism from the supply side and, therefore, that can lead to the integration of TS into FRIBS. And, as seen, ASIA, despite being a major source of data, presents critical issues that do not allow its use for TS.

Data collection on TS is carried out through the Intermediate Bodies at regional, provincial, sub-provincial level; it means that the registers of accommodation establishments are held by the bodies involved in the surveys, each one for its own territory of reference.

It follows that in Italy there is a highly different and heterogeneous situation, both in terms of who owns the registers (at political and administrative level) and what are the characteristics of the registers (at technical level).

\section{Tourism registers at local level}

To have a complete picture as this situation, Istat carried out an "ad hoc" survey in the second half of 2013: information had been collected through specific questionnaires submitted to the Intermediate Bodies responsible for the surveys on tourism.

The questionnaire was simple to fill, to ensure a response rate as high as possible, but at the same time it faced all the key elements useful to profile the LTR.

The first part of the questionnaire collected general information of the body: name, territory of reference, name of the contact person that is in charge of the surveys on tourism. In the second part, there were questions on the registers, for each type of accommodation:

- source of the register;

- timing of updates;

- coverage;

- information on the seasonal opening of the establishments (present in the register or obtained by other sources);

- use of the same register for the two surveys "Capacity" and "Occupancy". Otherwise, specification of the other sources;

- "Notes" for comments and / or additional information not covered in the previous questions.

Finally, it was asked to send also the record layouts of each tourism register to get a list of the variables.

The response rate was $96.8 \%$, therefore we succeeded in having information from almost all of the Intermediate Bodies. Lower, however, the rate of response regarding the transmission of the record layouts (about 54.8\%).

As we can see from the table n. 7, in Italy the registers of the accommodation establishments are in total 62 (13 at regional level and 49, regarding 7 regions, at provincial level).

From the results, we could identify the main features of the LTR. First of all, the unit of reference of all the registers is the LKAU.

With regard to the input sources of the registers, almost all are related to administrative compliances: the main source is the statement of the prices and the facilities ${ }^{10}$ (from $38.3 \%$ for hotels to $34.5 \%$ for farmhouses). Each Region is structured in different ways, both in terms of the body responsible for receiving the statements from the establishments, both in terms of deadlines and requirements.

Other administrative sources are, in order of importance: applications for classification of accommodation

${ }_{10}$ Mandatory administrative act (Law n. 284 of 25 August 1991, which established that Regions have to regulate the transmission and the publications of the prices and the facilities of the tourist accommodation establishments). 
Analysis and future Outlooks for Integration

establishments, that may be submitted to Regions or Provinces, depending on the local law in force ${ }^{11}$; other notifications (required by local regulations) and the SCIA (Certified Announcement on the Commencement of Activity) both submitted to Municipalities or Provinces. For the "Farm houses" other possible sources are specific administrative acts relating to other offices and bodies ( $8.6 \%$ of registers).

Table 7

N. of LTR in Italy and n. of Intermediate Bodies respondents to the survey

\begin{tabular}{|c|c|c|c|c|}
\hline region & N. of LTR & $\begin{array}{l}\text { N. of respondents } \\
\text { to the survey }\end{array}$ & $\begin{array}{l}\text { N. of record layouts } \\
\text { transmitted }\end{array}$ & territorial reference \\
\hline PIEMONTE & 1 & 1 & 1 & REG. \\
\hline VALLE D'AOSTA & 1 & 1 & 1 & REG. \\
\hline LOMBARDIA & 12 & 11 & 0 & PROV. \\
\hline LIGURIA & 1 & 1 & 0 & REG. \\
\hline AUTON.PROVINCIA OF BOLZANO* & 1 & 1 & 1 & PROV. \\
\hline AUTON.PROVINCIA OF TRENTO* & 1 & 1 & 0 & PROV. \\
\hline VENETO & 1 & 1 & 1 & REG. \\
\hline FRIULI VENEZIA GIULIA & 1 & 1 & 1 & REG. \\
\hline EMILIA-ROMAGNA & 9 & 8 & 6 & PROV. \\
\hline TOSCANA & 10 & 10 & 6 & PROV. \\
\hline UMBRIA & 1 & 1 & 1 & REG. \\
\hline MARCHE & 1 & 1 & 1 & REG. \\
\hline LAZIO & 1 & 1 & 0 & REG. \\
\hline ABRUZZO & 1 & 1 & 1 & REG. \\
\hline MOLISE & 2 & 2 & 1 & PROV. \\
\hline CAMPANIA & 5 & 5 & 0 & PROV. \\
\hline PUGLIA & 1 & 1 & 1 & REG. \\
\hline BASILICATA & 1 & 1 & 1 & REG. \\
\hline CALABRIA & 1 & 1 & 1 & REG. \\
\hline SICILIA & 9 & 9 & 9 & PROV. \\
\hline SARDEGNA & 1 & 1 & 1 & REG. \\
\hline TOTAL & 62 & 60 & 34 & \\
\hline RESPONSE RATE \% & & 96.8 & 54.8 & \\
\hline
\end{tabular}

Source: elaborations on Istat data - *The Autonomous Provinces of Bolzano and Trento in the Region Trentino-Alto Adige have legislative and administrative competencies as Regions.

About $18 \%$ of the registers is built using more sources, while about $15 \%$ take the information directly from the tourism accommodation establishments. This latter case is the most troublesome, since, basing only on the respondent establishments and not on administrative sources, it is harder to have reliable information about the actual coverage of the registers (see table n. 8).

About the coverage of the LTR, from the results it seems that the situation is comforting, since more than $80 \%$ of the registers has a full coverage, while only about $2 \%$ (from $1.7 \%$ to $3.4 \%$ ) has a low coverage (a third of the establishments).

The frequency of updates depends strictly on what is the input source of the registers: more than $60 \%$ of the LTR is updated continuously (especially those one that are built on the basis of several sources or notifications to Provinces or Municipalities); the bodies that use the statements of the prices and the facilities as

11 They are mandatory to obtain the classification according to the regional or provincial rules. 
principal source update registers twice a year or yearly (in accordance with the compulsory deadlines of this kind of administrative acts); finally, updates are monthly when information derive from the survey "Occupancy" (see table n. 9).

Table 8

Sources of the LTR

\begin{tabular}{|c|c|c|c|c|c|c|c|c|}
\hline & Hotels & $\begin{array}{l}\text { Camp- } \\
\text { sites and } \\
\text { holiday } \\
\text { villages }\end{array}$ & $\begin{array}{l}\text { Holiday } \\
\text { dwellings } \\
\text { (rented) }\end{array}$ & $\begin{array}{l}\text { Farm } \\
\text { houses }\end{array}$ & $\begin{array}{l}\text { Youth } \\
\text { hostels }\end{array}$ & $\begin{array}{l}\text { Holiday } \\
\text { homes }\end{array}$ & $\begin{array}{l}\text { Mountain } \\
\text { refuges }\end{array}$ & $B \& B$ \\
\hline Statement of the prices and the facilities & 38.5 & 36.8 & 36.8 & 34.6 & 35.5 & 37.2 & 36.9 & 36.8 \\
\hline Mix* & 18.3 & 18.3 & 18.3 & 17.2 & 18.6 & 16.9 & 16.7 & 18.3 \\
\hline Directly from establishments & 15.0 & 15.0 & 15.0 & 12.1 & 15.3 & 15.3 & 13.0 & 15.0 \\
\hline Application for classification & 10.0 & 10.0 & 10.0 & 5.2 & 8.5 & 10.2 & 9.3 & 8.3 \\
\hline $\begin{array}{l}\text { Various notifications made to the } \\
\text { municipal offices }\end{array}$ & 8.3 & 10.0 & 10.0 & 10.3 & 10.2 & 10.2 & 11.1 & 10.0 \\
\hline $\begin{array}{l}\text { Various notifications made to the } \\
\text { provincial offices }\end{array}$ & 3.3 & 3.3 & 3.3 & 3.4 & 3.4 & 3.4 & 3.7 & 3.3 \\
\hline SCIA & 3.3 & 3.3 & 3.3 & 3.4 & 3.4 & 3.4 & 3.7 & 3.3 \\
\hline $\begin{array}{l}\text { Lists at inspectorates of agriculture and } \\
\text { other specific offices }\end{array}$ & 0.0 & 0.0 & 0.0 & 8.6 & 0.0 & 0.0 & 0.0 & 0.0 \\
\hline Others & 3.3 & 3.3 & 3.3 & 5.2 & 5.1 & 3.4 & 5.6 & 5.0 \\
\hline Total & 100 & 100 & 100 & 100 & 100 & 100 & 100 & 100 \\
\hline
\end{tabular}

Table 9

Coverage and frequency of updates of the LTR

\begin{tabular}{|c|c|c|c|c|c|c|c|c|}
\hline \multicolumn{9}{|l|}{ Coverage } \\
\hline & Hotels & $\begin{array}{l}\text { Campsites } \\
\text { and holiday } \\
\text { villages }\end{array}$ & $\begin{array}{l}\text { Holiday } \\
\text { dwellings } \\
\text { (rented) }\end{array}$ & Farmhouses & $\begin{array}{l}\text { Youth } \\
\text { hostels }\end{array}$ & $\begin{array}{l}\text { Holiday } \\
\text { homes }\end{array}$ & $\begin{array}{l}\text { Mountain } \\
\text { refuges }\end{array}$ & $\mathrm{B} \& \mathrm{~B}$ \\
\hline Total & 85.0 & 85.0 & 83.3 & 82.8 & 84.7 & 81.4 & 81.5 & 81.7 \\
\hline Two-thirds of the establishments & 6.7 & 6.7 & 6.7 & 6.9 & 5.1 & 6.8 & 9.3 & 10.0 \\
\hline Half of the establishments & 1.7 & 0.0 & 1.7 & 0.0 & 0.0 & 1.7 & 0.0 & 0.0 \\
\hline One-third of the establishments & 1.7 & 3.3 & 1.7 & 3.4 & 1.7 & 3.4 & 1.9 & 3.3 \\
\hline Other & 4.9 & 5.0 & 6.6 & 6.9 & 8.5 & 6.7 & 7.3 & 5.0 \\
\hline Total & 100 & 100 & 100 & 100 & 100 & 100 & 100 & 100 \\
\hline \multicolumn{9}{|l|}{ Frequency of updates } \\
\hline & Hotels & $\begin{array}{l}\text { Campsites } \\
\text { and holiday } \\
\text { villages }\end{array}$ & $\begin{array}{l}\text { Holiday } \\
\text { dwellings } \\
\text { (rented) }\end{array}$ & Farmhouses & $\begin{array}{l}\text { Youth } \\
\text { hostels }\end{array}$ & $\begin{array}{l}\text { Holiday } \\
\text { homes }\end{array}$ & $\begin{array}{l}\text { Mountain } \\
\text { refuges }\end{array}$ & $B \& B$ \\
\hline Continuous & 63.3 & 61.7 & 63.4 & 62.1 & 62.7 & 62.7 & 63.0 & 63.4 \\
\hline Twice a year & 15.0 & 15.0 & 13.3 & 13.8 & 13.6 & 13.6 & 14.8 & 13.3 \\
\hline Monthly & 5.0 & 5.0 & 5.0 & 5.2 & 5.1 & 5.1 & 5.6 & 5.0 \\
\hline Yearly & 6.7 & 6.7 & 8.3 & 8.6 & 8.5 & 8.5 & 5.6 & 8.3 \\
\hline Other & 10.0 & 11.6 & 10.0 & 10.3 & 10.1 & 10.1 & 11.1 & 10.0 \\
\hline Total & 100 & 100 & 100 & 100 & 100 & 100 & 100 & 100 \\
\hline
\end{tabular}

Almost all of the Intermediate Bodies have the register that includes also information on the seasonal opening/closing of the establishments. Only $8.3 \%$ of the registers $(11.7 \%$ for farmhouses) does not have this information, deriving it from a separate register $(60 \%$ of this $8.3 \%)$ or from the survey $(40 \%)$. 
Analysis and future Outlooks for Integration

In addition, $96.7 \%$ of the LTR contains the information necessary for both the survey "Capacity" and "Occupancy" and, therefore, are used for both at the same time.

\section{Analysis of the record layouts of the local registers}

To get an accurate description of what information is present in the several LTR, an analysis on their record layouts was carried out (34 on 60 registers).

First of all, it should be pointed out that in almost all the registers there are the basic variables of the two surveys on tourism.

The first variable on which we focused is the "identification code of the establishment"; the bodies use different practices one from another, but they can be summarized in three main types: use of an "administrative code" (number deriving from administrative acts); use of a "progressive code" 12 ; use of a "complex identification $\operatorname{code}^{13} "$. The most widely used method is the "progressive code" (52.9\% of the analyzed record layouts), followed by the "complex identification code" (32.4\%) and by the "administrative code" (14.7\%).

Table 10

Type of identification code in the LTR

\begin{tabular}{lll}
\hline Identification code & Answers & $\%$ \\
\hline Administrative code & 5 & 14.7 \\
Progressive code & 18 & 52.9 \\
Complex identification code & 11 & 32.4 \\
TOTAL & 34 & 100 \\
\hline
\end{tabular}

The tax code or the VAT number of the units are not used as identification code in any register. This is very relevant because in ASIA registers this information is the main link-key, capable to identify univocally an enterprise (and its local units). Only 4 record layouts have the variable "tax code" or "VAT number", so a linkage between the local registers and ASIA presents many operative difficulties.

This lack could be overcome through the joint use of a set of variables, that can identify common records. Knowing the record layout of ASIA and the statistical record linkage procedures normally used for the creation and the updating of the lists of ASIA, we analyzed the record layouts of the LTR to check if these variables are present.

The table below shows that just over $91 \%$ of the analyzed record layouts contains the variable "address of the establishment", just over $88 \%$, "name of the establishment", while only $32.4 \%$ includes information about the owners (name, tax code). The percentage of the LTR that have all the three variables is only $32.4 \%$.

Table 11

Presence of "secondary key" variables in the LTR

\begin{tabular}{lllll}
\hline & Address & Name of the establishment & Variables on the owners & The three variables together \\
\hline $\begin{array}{l}\text { n. record layouts } \\
\text { \% on the tot. of record }\end{array}$ & 31 & 30 & 11 & 11 \\
layouts (34) & 91.2 & 88.2 & 32.4 & 32.4 \\
\hline
\end{tabular}

Of course, any use of such variables would need preliminary standardization procedures and deterministic or probabilistic record linkage procedures, depending on the quality of the variables.

\footnotetext{
12 Namely, when a new unit is inserted in the database, this one is associated with the first free number in sequential order.

13 A code that can be composed of more numeric or alphabetic characters, for example a code composed by the province code + initials of name + a code that identifies the type of establishment.
} 
Obviously, as we are going to describe in the next paragraph, these are issues that Istat should face also in event that the Institute will plan to acquire and to link all the LTR to achieve a single register of all the accommodation establishments.

Finally, since the Regulation 692/2011 requires that, starting from the data regarding the year 2015, each MS has to collect and to transmit to Eurostat also the number of hotels and similar accommodation having one or more bedrooms accessible for persons with reduced mobility, including wheelchair users, we checked also the presence of this kind of information in the LTR. At this moment, only $11.8 \%$ of the analyzed record layouts has proxy variables on the accessibility for disabled people and not always regarding rooms, but bathrooms instead.

\section{Critical issues for the linkage of local registers}

From the analysis described above, a quite accurate picture of the LTR arises so that we can make some first considerations on their possible linkage into a single national register.

The first remarkable consideration is that the LTR together cover the whole country, but they are a very large number (62 in total), they have different territory of reference (Region or Province) and they are held by different local bodies. The acquisition by a single Institution (for instance, Istat) of all the LTR seems hard for administrative and mainly for political reasons; in fact, the Regions, that have legislative competence in the field of tourism, have invested resources over the years in their registers, that they currently use, not only for statistical purposes, but also for their tourism development policies and economic planning at local level.

Other not minor technical-operational difficulties can be summarized in three main topics:

(1) methodological-statistical issues regarding the linkage of 62 LTR to build up a single national tourism register;

(2) management and updating issues of the register, because the administrative sources from which the LTR derive are several and they have different times and ways of updating;

(3) IT issues, because at the moment each local register has its own structure and physical support, its own conceptual logic, a specific software that manages and organizes the database and its own programming language.

\section{Final Remarks}

The aim of creating a national tourism register, as a satellite archive of ASIA, would require a considerable effort in terms both of resources and will of the many bodies involved.

If there were these essential conditions, it would realize an institutional framework in which Istat would be the coordinator of the activities regarding the building up of a national tourism register and the Intermediate Bodies, as co-partners, would keep on manage and update their local "piece" of register.

The fulfillment of the project appears difficult and with very long times.

Effectively, after the acquisitions of the LTR, the macro-process phases to be performed are the following:

- defining a single "database": identifying a minimum set of variables for the national tourism register, to be populated using the local archives;

- standardization and normalization of the information contained in the various archives. First of all, a unique identification code for the units should be established, so that it can also be used for the linkage with 
Analysis and future Outlooks for Integration

ASIA registers ${ }^{14}$. The best choice would be that the Intermediate Bodies acquire the tax code or VAT number of the accommodation establishments;

- identifying each input local archive with an identification code to not lose the link of each information with the original source;

- creation of another "database", connected to the main one, where all the other variables, outside the minimum core variables, are stored.

The actions for building up a single national tourism register and, therefore, for a systematic use of the existing administrative sources at the local level have - certainly - relevant implications in the processes of production, in the organizational structure and in the inter-institutional relations, but, on the other hand, it goes in the direction of the increasing use of administrative data, considering the advantages it takes such as cost reduction, reduction of the burden on respondents and deeper control over the coverage of the target population.

\section{References}

Eurostat, 2013a. Integration of tourism statistics into business statistics: state of affairs on FRIBS, Document Eurostat/G3 TOUR-WG-2013-09.

Eurostat, 2013b. FRIBS: Strategic progress overview for Business Registers and statistical units, Document doc.3_1, BSDG/24-25 June 2013.

Eurostat, 2013c. FRIBS: strategic progress overview of tourism statistics, Document doc.08, BSDG/24-25 June 2013.

Eurostat, 2012a. FRIBS: framework regulation integrating business statistics, Document doc.02 Eurostat/GE TOUR WG SEPT 2012.

Eurostat, 2012b. FRIBS: exploration on a 'tourism package', Document doc.03 Eurostat/GE TOUR WG SEPT 2012.

Eurostat, 2012c. Methodological manual for tourism statistics, version 1.2, Publications Office of the European Union, Luxembourg.

Istat, anni vari. Nota metodologica Struttura e dimensione delle imprese, Roma.

Regulation (EU) No 692/2011 of the European Parliament and of the council of 6 July 2011 concerning European statistics on tourism and repealing Council Directive 95/57/EC.

\footnotetext{
14 A special treatment should be done to those accommodation out of scope of ASIA.
} 